\title{
JELAJAH VIRTUAL PUBLIC PLACES MELALUI PENGGUNAAN BARCODE DALAM TEKS INTERAKSI TRANSAKSIONAL
}

\author{
VIRTUAL EXPLORATION OF PUBLIC PLACES THROUGH BARCODE IN \\ TRANSACTIONAL INTERACTION TEXT
}

\author{
SRI SURYANTI
}

SMPN 22 Bandung

\begin{abstract}
Received: March 09, 2021

This study aims to improve the ability to express the students' opinion in exploring the virtual Revised: September 30, 2021 of public places through barcodes. Through a qualitative approach, data collection was taken Accepted: November 26, 2021 from 33 students in Class 7.06. The test of result data in cycles 1 and 2 experienced increasing in student learning outcomes which referred to the criteria of score minimum of 67, with description of the predicate $A$ to $D$ as follows: 1) needs to be maximized (D), 2) enough (C), 3) good (B), 4) excellent (A). Strengthening students' digital literacy skills in using barcodes through android applications, 87\% succeeded in downloading the QR Code Scanner application, 13\% failed to download due to limited HP memory capacity and internet quota. This research is expected to provide meaningful information for English teachers in learning transactional text material about public places to improve students' speaking skills as a learning tool that becomes a provision in real life in the surrounding environment
\end{abstract}

\begin{abstract}
Abstrak.
Penelitian ini bertujuan untuk meningkatkan kemampuan berbicara melalui teks interaksi transaksional peserta didik dalam menjelajahi secara virtual tempat-tempat umum (public places) dan mengungkapkan pendapat melalui penggunaan barcode. Melalui pendekatan kualitatif, pengumpulan data diambil dari peserta didik di Kelas 7.06 berjumlah 33 orang melalui tahapan berikut: 1) Observasi, sebagai tahapan diagnostik mengenai kemampuan peserta didik dalam memberi dan menerima informasi dengan cara menjelaskan tempat-tempat umum dibantu media peta; 2) Angket/kuesioner, mengenai kesulitan belajar yang dihadapi dalam mengungkapkan pendapat mengenai tempat-tempat umum, 3) Angket/kuesioner, tanggapan para peserta didik mengenai jelajah virtual melalui penggunaan barcode; 4) nilai keterampilan berbicara peserta didik dalam menjelaskan tempat-tempat umum pada siklus 1 dan 2 meningkat, dapat terlihat dari hasil prates dan postes serta keaktifan selama proses belajar berlangsung. Data hasil tes pada siklus 1 dan 2 mengalami peningkatan hasil belajar pada peserta didik yang mengacu pada nilai KKM 67, dengan uraian predikat $A$ s.d. D, sebagai berikut: 1) predikat yang perlu dimaksimalkan (D), 2) predikat cukup (C), 3) predikat baik (B), 4) predikat sangat baik (A). Penguatan kemampuan literasi digital peserta didik dalam penggunaan barcode melalui aplikasi android, 87\% berhasil mendowload aplikasi QR Code Scanner, 13\% tidak berhasil mendownload dikarenakan keterbatasan kapasitas memori HP dan quota internet. Penelitian ini diharapkan dapat memberikan informasi berguna bagi para guru Bahasa Inggris dalam pembelajaran materi teks transaksional tentang tempat-tempat umum untuk peningkatan kemampuan berbicara para peserta didik sebagai sarana pembelajaran yang menjadi bekal dalam kehidupan nyata di lingkungan sekitarnya
\end{abstract}

Keywords: $\quad$ Transactional Interaction Text, Virtual Exploration, Barcode

Kata kunci: $\quad$ Teks Interaksi Transaksional, Jelajah Virtual, Barcode

$\left(^{\star}\right)$ Corresponding Author: $\quad$ sri.suryanti1972@gmail.com

How to Cite: Suryanti, S., (2021). Jelajah Virtual Public Places Melalui Penggunaan Barcode Dalam Teks Interaksi Transaksional. Jurnal Lingkar Mutu Pendidikan, 18 (2), 210-215. https://doi.org/10.54124/jlmp.v18i1.34

\section{PENDAHULUAN}

Dalam membentuk konteks belajar Bahasa Inggris yang dapat menunjang penggunaan bahasa lisan peserta didik, harus diupayakan pembelajaran menggunakan bahasa lisan yang mudah dipahami. Disadari bahwa untuk menyiapkan sumber daya manusia yang mampu menghadapi era globalisasi 
maka pendidikan, termasuk pendidikan Bahasa Inggris, harus dapat menjadi bekal yang memadai agar lulusan sekolah dapat berkompetisi dalam berbagai kegiatan akademik, sosial, ekonomi, dan sebagainya.

Proses belajar merupakan suatu kebutuhan seiring makin pesatnya kemajuan ilmu dan teknologi menimbulkan berbagai perubahan pada berbagai aspek kehidupan manusia. Tanpa belajar, manusia akan mengalami kesulitan dalam menyesuaikan diri dengan lingkungannya (Basleman, 2011:1). Terkait dengan pendidikan, belajar adalah suatu proses kala manusia dapat memperoleh pengetahuan baru, keterampilan baru serta kemampuan memaknai satu nilai baru dalam kehidupannya (Soekanto, 2006).

Dalam pelaksanaannya, proses pembelajaran dirancang secara interaktif, menyenangkan, menantang, inspiratif, dan memotivasi peserta didik untuk berpartisipasi aktif sesuai Pembelajaran Aktif, Kreatif, Efektif dan Menyenangkan (PAKEM) yang tertuang pada PP No. 19. 2005. Bab IV Pasal 19 Ayat 1, yang meyediakan ruang yang memadai untuk prakarsa, kreativitas, dan kemandirian yang harus sesuai dengan bakat, minat, dan perkembangan fisik dan psikologis peserta didik.

Kenyataan di lapangan, untuk membiasakan diri peserta didik berbahasa Inggris secara praktik baik lisan maupun tulis tidaklah mudah apalagi dengan dialek kedaerahan yang begitu melekat pada peserta didik dan keterbatasan kosakata yang dimiliki. Oleh karena itu perlu model dan media pembelajaran yang tepat dan efektif guna membantu permasalahan yang ada. Model dan media pembelajaran yang sudah ada seperti, alat bantu berupa gambar-gambar pendukung PBM, kaset serta film-film dalam bentuk CD belum membantu secara signifikan.

Bila melihat kompetensi yang wajib dikuasai oleh peserta didik dalam 4 keahlian (skills); listening, speaking, reading, writing, tentunya masih banyak permasalahan yang ada dalam keahliankeahlian tersebut, seperti yang pernah dilakukan dalam penelitian Sukardi (2015), dengan cara mengembangkan model konstruktivistik melalui multi media pembelajaran bahasa Inggris tema Public Places and Sports di kelas VIII SMP semester genap dalam bentuk CD pembelajaran, dan media yang dikembangkan untuk meningkatkan capaian empat keterampilan bahasa Inggris di sekolah.

Hasil ujicoba media tersebut lebih berdampak pada kemampuan peserta didik dengan suka belajar menggunakan multimedia, oleh karenanya, penulis membatasi permasalahan hanya dari keahlian berbicara (speaking), walaupun dalam pelaksanaan penelitiannya tetap bersifat terpadu (integrated skills). Dalam proses mengajarkan speaking, timbul beberapa permasalahan diantaranya; kesulitan dalam mengungkapkan ide, pronunciation yang kurang tepat, kesulitan dalam mengorganisasi kalimat sederhana, melakukan tanya jawab secara langsung.

Penulis ingin menjelaskan permasalahan kemampuan berbicara yang berkaitan dengan teks interaksi interpersonal dalam memberi dan menerima informasi. Hal itu karena terdapat beberapa peserta didik yang mendapat kesulitan dalam mengemukakan pendapat terkait memberikan penjelasan tempat-tempat umum yang ada di lingkungan sekitarnya.

Hal ini menjadi latar belakang penulis untuk melakukan penelitian tindakan kelas melalui penggunaan media barcode. Maka penulis mengambil judul sebagai berikut; "Jelajah Virtual Public Places melalui Penggunaan Barcode dalam Teks Interaksi Transaksional". Penelitian ini dilakukan untuk menjawab pertanyaan, "bagaimanakah kemampuan peserta didik dalam mempelajari materi tentang teks interaksi transaksional mengenai public places bila dilakukan tindakan pembelajaran melalui penggunaan barcode?"

Untuk menemukan solusi pada permasalahan pengajaran teks interaksi transaksional agar guru dapat mengaktifkan dan memotivasi peserta didik sehingga proses pembelajaran menjadi lebih bermakna dan hasil belajar menjadi lebih baik; untuk memotivasi; dapat meningkatkan minat dalam melakukan penelitian sebagai upaya meningkatkan profesionalisme dan bersikap ilmiah.

Manfaat penelitian bisa dijadikan rujukan pembelajaran dalam mempelajari model-model ungkapan memberi dan meminta informasi dari teks sederhana yang diintegrasikan dengan ICT; dapat meningkatkan keberanian peserta didik untuk mengungkapkan pendapat tentang memberi dan meminta informasi terkait tempat-tempat umum yang ada di lingkungan sekolah berdasarkan pengamatan terhadap gambar yang diberikan melalui barcode; meningkatkan kualitas pembelajaran 
dan keterampilan menggunakan beragam teknik dan media pembelajaran; serta meningkatkan kemampuan berbicara peserta didik.

Menurut sumber pembelajaran PKP zonasi, Kemdikbud (2019), teks transaksional digunakan dalam kehidupan sehari-hari saat berkomunikasi dengan orang lain dengan tujuan untuk mendapatkan atau memberi informasi tertentu (information change) atau menyelesaikan sesuatu (to get things done). Teks transaksional juga bertujuan untuk memenuhi kebutuhan hidup, seperti meminta informasi, menawar, meminjam, dll.

Teks ini terdapat dalam materi pembelajaran Bahasa Inggris SMP/MTs berdasarkan standar BSNP terbagi menjadi tiga, yaitu terkait lingkungan terdekat, lingkungan sekitar, dan interaksi dalam konteks kehidupan sehari-hari. Teks yang menjadi fokus dalam pembelajaran ini berkaitan dengan lingkungan terdekat.

Teks transaksional terkait lingkungan terdekat antara lain: memberi dan merespon sapaan; memperkenalkan diri sendiri dan orang lain; meminta dan memberi informasi; meminta dan memberi jasa; meminta dan memberi barang; meminta dan memberi fakta; meminta dan memberi pendapat; mengucapkan terima kasih; meminta dan memberi maaf; menggunakan ungkapan kesantunan; menyatakan suka dan tidak suka; meminta klarifikasi.

Jelajah Virtual menurut KBBI versi 5 (2016), memiliki makna telusuri internet dengan menggunakan perangkat lunak komputer/laptop/ gadget. Dalam penelitian ini, jelajah virtual melalui google map dijadikan digital tools dalam pembelajaran.

Aplikasi bawaan adalah aplikasi yang wajib dan selalu ada di seluruh produk smartphone android (Wahadyo, 2013:3). Salah satu aplikasi yang dapat dijadikan sarana belajar Bahasa Inggris adalah aplikasi bawaan smartphone android yaitu Google Maps. Google maps merupakan layanan peta yang menampilkan gambar lokasi jalanan dan tingkat kemacetan lalu lintas yang ada di seluruh dunia.

Untuk menggunakan Google Maps secara maksimal, dibutuhkan pula koneksi jaringan internet yang lancar. Beberapa negara telah bekerja sama dengan Google untuk mendukung perkembangan teknologi mereka. Namun di sisi lain beberapa pemilik bisnis juga meminta Google untuk dapat memberikan akses kepada gedung tempat usaha mereka, agar banyak publik yang melihatnya.

Berdasarkan kamus komputer dan teknologi informasi, barcode memiliki arti kode batang. Kode berbentuk batangan balok dan berwarna hitam putih, mengandung satu kumpulan kombinasi batang yang berlainan ukuran dan disusun sedemikian rupa yang dicetak di atas stiker atau di kotak bungkusan barang. Kode ini mewakili data atau informasi tertentu (biasanya jenis dan harga barang seperti makanan dan buku).

Alat yang digunakan untuk membaca barcode adalah barcode scanner. Alat ini dapat membaca informasi/data dengan kecepatan yang jauh lebih tinggi dibanding dengan mengetikkan data, selain itu juga memiliki tingkat ketelitian yang lebih tinggi.

Kode batang, kode palang, atau kode bar (barcode) adalah suatu kumpulan data optik yang dibaca mesin. Kode ini mengumpulkan data dalam lebar (garis) dan spasi garis paralel, disebut sebagai kode batang atau simbologi linear atau 1D (1 dimensi). Tetapi juga memiliki bentuk persegi, titik, heksagon dan bentuk geometri lainnya dalam gambar yang disebut kode matriks atau simbologi 2D (2 dimensi).

\section{METODOLOGI PENELITIAN}

Penelitian dilaksanakan pada SMP Negeri 22 Bandung menggunakan sampel dengan karakteristik yang sama berjumlah 33 orang dari Kelas 7.06, sejumlah 15 orang laki-laki, dan 18 orang perempuan. Agenda penelitian selama bulan November 2019 dalam 2 siklus sebanyak 4 pertemuan, dan alokasi waktu dalam setiap pertemuan $2 \times 40$ menit. Tahapan penelitian melalui tindakan-tindakan sebagai berikut: pembentukan kelompok menjadi 6 kelompok yang masing-masing berjumlah 5 orang. Pengelompokkan dilihat dari tingkat kemampuan Bahasa Inggris, kemampuan ICT serta kepemilikan HP android.

Pengumpulan data penelitian ini diambil melalui: Observasi, melalui tahapan diagnostik mengenai kemampuan berbicara peserta didik dengan cara menjelaskan tempat-tempat umum tanpa dibantu media; Angket/kuesioner, mengenai kesulitan belajar yang dihadapi dalam mengungkapkan pendapat 
mengenai tempat-tempat umum; Angket/kuesioner, tanggapan para peserta didik mengenai jelajah virtual melalui penggunaan barcode; nilai keterampilan berbicara peserta didik dalam menjelaskan tempat-tempat umum diantara teman, saling mengungkapkan ide masing-masing.

\section{HASIL DAN PEMBAHASAN}

Hasil penelitian diambil dari hasil prates dan postes dari 2 siklus, yaitu: Siklus 1 ( 2 x pertemuan), melalui tahapan penjelasan konsep teks interaksi transaksional, menjelaskan tempat-tempat umum di sekitar lingkungan terdekat. Temuan pada Siklus 1 sebagai dasar pada Siklus 2 ( 2 x pertemuan), untuk melengkapi kekurangan/kelemahan yang terjadi pada siklus sebelumnya. Pada siklus ini peserta didik menjelajahi tempat-tempat umum secara virtual melalui barcode yang diberikan guru, yang dihubungkan melalui google map, terkait tempat-tempat umum yang terdekat ke sekolah dan tempat tinggal peserta didik.

Berdasarkan hasil observasi Siklus Pertama dan Kedua, menunjukkan bahwa pelaksanaan pembelajaran secara umum sesuai dengan desain RPP dengan menggunakan model pembelajaran discovery learning, sejalan dengan sintak model yang dilakukan oleh Astuti, dkk. (2018) dengan judul "Penerapan Model Pembelajaran Discovery Learning untuk Meningkatkan Hasil Belajar pada Materi Biologi Siswa SMP".

Aktivitas guru selama pembelajaran antara lain: memberitahu peserta didik tentang program dan tujuan pembelajaran; sebagai fasilitator memfasilitasi kebutuhan peserta didik dalam melakukan scaffolding, eksplorasi dan elaborasi; merancang desain pembelajaran; mendorong peserta didik dapat aktif dalam proses tanya jawab selama pembelajaran berlangsung; membimbing peserta didik untuk melakukan tanya jawab dari teks interaksi transaksional yang diberikan.

Penguatan pada siklus kedua, melalui aktivitas guru dalam proses pembimbingan peserta didik melalui kegiatan: mendowload aplikasi QR Code Scanner dari playstore HP android, memberitahukan proses memindai dari link yang diberikan; merancang desain pembelajaran; mendorong peserta didik dapat aktif dalam proses tanya jawab selama pembelajaran berlangsung; membimbing peserta didik untuk melakukan tanya jawab dari teks interaksi transaksional yang diberikan melalui penggunaan barcode.

Aktivitas peserta didik selama pembelajaran meliputi: menyimak program dan tujuan pembelajaran yang disampaikan; merespon dengan benar apa yang disampaikan oleh guru; mengamati gambar tentang tempat-tempat umum yang disajikan melalui foto-foto yang disajikan oleh guru; mengumpulkan dan mengolah data jarak yang ditempuh dari tempat-tempat umum ke sekolah dengan menggunakan peta; menuliskan nama dan fungsi bangunan publik di buku masing-masing; memverifikasi tempat-tempat umum yang dapat dijangkau dengan mudah dari sekolah dengan menjelaskan posisi tempatnya dengan benar melalui jarak yang tertera dalam peta; menyimpulkan tempat-tempat umum yang dapat dijangkau dengan mudah dari sekolah.

Penguatan pada siklus kedua, melalui aktivitas peserta didik selama pembelajaran meliputi: menyimak program dan tujuan pembelajaran yang disampaikan; merespon dengan benar apa yang disampaikan oleh guru; memindai link gambar tentang tempat-tempat umum melalui QR Code Scanner melalui HP android masing-masing; mencermati gambar-gambar dan ragam instruksi yang ditampilkan; mengumpulkan dan mengolah data jarak yang ditempuh dari tempat-tempat umum ke sekolah dengan menggunakan google map; menuliskan nama dan fungsi bangunan publik di buku masing-masing atau google doc; memverifikasi tempat-tempat umum yang dapat dijangkau dengan mudah dari sekolah dengan menjelaskan posisi tempatnya dengan benar melalui titik koordinat yang tertera dalam google map; menyimpulkan tempat-tempat umum yang dapat dijangkau dengan mudah dari sekolah dari hasil pengamatan masing-masing titik koordinat yang tertera dalam google map; melakukan analisis jarak antara tempat-tempat umum ke sekolah bersama kelompok; termotivasi, memiliki semangat yang bagus dan bertanggung jawab untuk menyelesaikan tugas-tugas yang dianggap rumit; masing-masing kelompok dapat berkerjasama dengan baik. 
Tabel. Data Frekuensi Tes Akhir Siklus 1 dan 2

\begin{tabular}{|c|c|c|c|c|c|c|}
\hline \multirow{2}{*}{ No } & \multirow{2}{*}{ Nilai } & \multicolumn{2}{|c|}{ Siklus 1} & \multicolumn{2}{|c|}{ Siklus 2} & \multirow{2}{*}{$\begin{array}{c}\text { Presentase } \\
\text { Capaian } \\
\text { Kompetensi }\end{array}$} \\
\hline & & Frekuensi & Persentase & Frekuensi & Persentase & \\
\hline 1 & $45-52$ & 6 & \multirow{3}{*}{$63.64 \%$} & 0 & & \multirow{2}{*}{$45.64 \%$} \\
\hline 2 & $53-60$ & 7 & & 0 & $18.00 \%$ & \\
\hline 3 & $61-66$ & 8 & & 6 & & \\
\hline 4 & $67-78$ & 7 & $21.00 \%$ & 5 & $15.00 \%$ & $6 \%$ \\
\hline 5 & $79-89$ & 4 & $12.00 \%$ & 19 & $58.00 \%$ & $7 \%$ \\
\hline 6 & $90-100$ & 1 & $3.00 \%$ & 3 & $9.00 \%$ & $6 \%$ \\
\hline & Jumlah & 33 & $100 \%$ & 33 & $100 \%$ & \\
\hline
\end{tabular}

Berdasarkan tabel distribusi frekuensi di atas, data hasil tes pada siklus 1 dan 2 mengalami peningkatan hasil belajar peserta didik, diantaranya: 1) predikat yang perlu dimaksimalkan mengalami perbaikan $45.64 \%$, 2) predikat cukup dari rentang nilai 67 s.d. 78 mengalami perbaikan 6\%, 3) predikat baik dari rentang nilai 79 s.d. 89 mengalami perbaikan 7\%,4) predikat sangat baik dari rentang nilai 90 s.d. 100 mengalami perbaikan $6 \%$.

Manfaat TIK dan internet dalam pembelajaran melalui hasil kuesioner kepada para peserta didik menghasilkan 47\%, TIK dapat membantu mengerjakan tugas, 67\% untuk membantu memudahkan proses pembelajaran sehingga lebih menarik, $73 \%$ untuk pengembangan pribadi dalam menambah wawasan dan pengetahuan melalui internet, 30\% untuk membantu mengembangkan jaringan sosial dengan sesama teman melalui e-mail/facebook, dan 10\% untuk chating, browsing photo/gambargambar kartun dll. Internet, 67\% bermanfaat untuk membuat bahan tugas, 53\% mencari bahan pendukung tugas belajar, $23 \%$ bergabung dengan forum tertentu, $30 \%$ bermain game/permainan, $10 \%$ untuk iseng saja.

Keberhasilan menginstal aplikasi QR Code Scanner, 87\% sudah berhasil dan 13\% belum berhasil, dikarenakan memory HP penuh dan tidak mendukung kapasitas di HP serta tidak memiliki quota internet yang memadai untuk mendownload. Ketertarikan peserta didik dalam mempelajari materi tentang tempat-tempat umum menggunakan link barcode, 97\% menyatakan senang belajar dengan menggunakan digital tool melalui barcode, dan 3\% menyatakan tidak dengan alasan keterbatasan kapasitas memory HP dan quota internet.

Pemahaman peserta didik tentang teks interaksi transaksional melalui penggunaan barcode, $85 \%$ menyatakan menjadi mudah dipahami dengan alasan pada link yang diberikan melalui barcode disajikan gambar interaktif dan ragam latihan yang bervariasi dalam memberi dan meminta informasi terkait tempat-tempat umum.

\section{SIMPULAN DAN SARAN}

Penelitian ini telah mengkaji penggunaan barcode dalam teks interaksi transaksional di Kelas 7.06 SMP Negeri 22 Bandung, dari data hasil tes pada siklus 1 dan 2 mengalami peningkatan hasil belajar peserta didik yang mengacu pada nilai KKM 67, dengan uraian predikat A s.d. D, sebagai berikut: 1) predikat yang perlu dimaksimalkan (D),2) predikat cukup (C),3) predikat baik (B), 4) predikat sangat baik (A).

Kemampuan ICT peserta didik mengaplikasikan barcode meningkat, terbukti dengan $87 \%$ peserta didik pada Siklus 2 dapat mengakses dengan mudah ke aplikasi playstore dan 13\% peserta didik yang belum berhasil dikarenakan kapasitas memori HP penuh, quota internet yang kurang memadai; kemampuan peserta didik dalam memberi dan menerima informasi terkait teks interaksi transaksional meningkat, peserta didik tertantang untuk melakukan tanya jawab dengan penyajian visual dan ragam aktivitas yang menarik melalui gambar dari tempat-tempat umum yang disajikan melalui link barcode; pembelajaran aktif, kreatif, menarik, dan menyenangkan melalui hasil kuesioner yang dilakukan setelah pembelajaran sebesar $97 \%$ peserta didik menyukai pembelajaran menggunakan barcode.

Pembelajaran menjadi lebih bermakna apabila peserta didik terlibat dan mengalami pengalaman pembelajaran. Hal ini menuntut kreativitas guru dalam mengolah dan mendesain pembelajaran agar lebih mudah dipahami dalam jangka waktu yang panjang. 
Seiring dengan kemajuan bidang IT begitu pesat, tentunya IT juga sangat berperan besar dalam proses pembelajaran. Untuk mendukung hal ini tentunya pihak sekolah juga perlu melengkapi sarana dan prasarana yang lebih baik, bukan hanya sumber belajar di perpustakaan tetapi juga berupa digital tool dalam bentuk digital library yang manfaatnya begitu besar sebagai alat bantu belajar dan juga referensi penyelesaian tugas peserta didik.

\section{PUSTAKA ACUAN}

Astuti, Theresia Inovia, dkk. 2018. Penerapan Model Pembelajaran Discovery Learning untuk Meningkatkan Hasil Belajar pada Materi Biologi Siswa SMP. Jurnal Pendidikan dan Pembelajaran Biologi Volume 2 Nomor 1.

Basleman, Anisah. 2011. Teori Belajar Orang Dewasa. Bandung: PT Remaja Rosdakarya.

Kamus Besar Bahasa Indonesia (KBBI). 2016. Versi 5. Badan Pengembangan dan Pembinaan Bahasa. Balai Pustaka. Kementerian Pendidikan dan Kebudayaan Indonesia.

PP No. 19. 2005. Bab IV Pasal 19 Ayat 1. Pembelajaran PAKEM -Aktif, Kreatif, Efektif dan Menyenangkan. Kementerian Pendidikan dan Kebudayaan. Jakarta.

PKP Zonasi. 2019. Kementerian Pendidikan dan Kebudayaan. Jakarta.

Soekanto, Soerjono. 2006. Sosiologi Suatu Pengantar. Jakarta: Rajawali Press.

Sukardi. 2015. Model Konstruktivistik Membangun Konsep Pembelajaran Bahasa Inggris Kelas VIII SMP Negeri 4 Siantan Pontianak. Jurnal Pendidikan dan Pembelajaran Khatulistiwa. Volume 4, No. 11.

Wahadyo, Agus. 2013. Android 4 untuk Pengguna Pemula Tablet dan Handphone. Jakarta: Media Kita. 